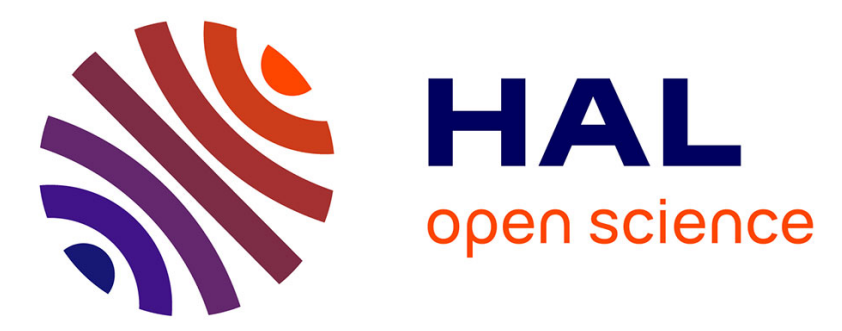

\title{
Celebrating the October Revolution? A Socialist Dilemma: France, Italy, 1945-1956 \\ Virgile Cirefice
}

\section{To cite this version:}

Virgile Cirefice. Celebrating the October Revolution? A Socialist Dilemma: France, Italy, 19451956. Twentieth Century Communism: a journal of international history, 2017, 13 (13), pp.17-40. 10.3898/175864317822165077 . halshs-02434484

\section{HAL Id: halshs-02434484 \\ https://shs.hal.science/halshs-02434484}

Submitted on 8 Feb 2020

HAL is a multi-disciplinary open access archive for the deposit and dissemination of scientific research documents, whether they are published or not. The documents may come from teaching and research institutions in France or abroad, or from public or private research centers.
L'archive ouverte pluridisciplinaire HAL, est destinée au dépôt et à la diffusion de documents scientifiques de niveau recherche, publiés ou non, émanant des établissements d'enseignement et de recherche français ou étrangers, des laboratoires publics ou privés. 


\section{Celebrating the October Revolution?}

A Socialist Dilemma: France, Italy, 1945-1956

\section{Working paper}

\section{Virgile Cirefice - Université Paris 8 - Università di Bologna}

Tackling the issue of the October Revolution celebration through the angle of a dilemma conveys the idea that socialists necessarily have a special bond with the Russian revolution. The Partito Socialista Italiano (Italian Socialist Party or $\mathrm{PSI}^{1}$ ) and the Section Française de l'Internationale Ouvrière (French Section of the Worker's International or SFIO) were both refounded in the 1940s after a period of clandestinity and both insisted on their marxist identity. Most of the time, they presented themselves as revolutionary parties, as representatives of the working class, and they called for a social transformation of society. After the political revolutions of the nineteenth century and the political equality that was achieved through them, the goal was to put the working classes in power by a social revolution that would establish equality in the economic sphere. At the time, the ultimate embodiment of a social revolution was the Russian revolution: since 1917, for its partisans as much as for its opponents, it embodied the idea of the Revolution. ${ }^{2}$ The French might have tried to bring up the example of the Paris Commune, whose symbolic legacy they fought over with the communists by organising rival commemorations; but it clearly did not have the same symbolic power, especially after Stalingrad and the great prestige the Soviet Unionthen enjoyed. ${ }^{3}$

And yet, to a socialist, it was an event full of ambiguity. No-one could ignore the split of the European working-class movement around Lenin's twenty-one conditions for admission to the Comintern, and the heated congresses in Tours (1920) and Livorno (1921) which had resulted in the creation of the French and Italian communist parties. Furthermore, in collective representations, it was unquestionable that the very same communist parties were the successors of the October Revolution. Additionally, after the Second World War, socialist parties were torn between opposing branches, one wishing to take advantage of the new conditions arising from the Liberation to move closer to the communist party, the other still wary of its 'sister party'.

Both parties were therefore faced with a tough alternative to tackle: should they commemorate an event whose prestige would undeniably reinforce the communist party's audience? If they failed to do this, could they call themselves representatives of the working class while ignoring the greatest event relevant to them in the twentieth century? One must

\footnotetext{
${ }^{1}$ From its refoundation in 1943 until 1947, it was called the Partito Socialista Italiano di Unità Proletaria (United Proletarian Italian Socialist Party or PSIUP).

${ }^{2}$ For instance, Marcello Flores, 'Il mito dell'URSS nel secondo dopoguerra' in Pier Paolo d'Attorre, Nemici per la Pelle: Sogno Americano e Mito Sovietico nell'Italia Contemporanea, Milan: Franco Angeli, 1991, p493: 'Except for a small radical branch [...] in Italy, maybe even more than anywhere else, everyone agreed, both partisans of and opponents to the USSR, to consider the soviet regime as utterly socialist'.

${ }^{3}$ About the evocative power of the USSR for socialists, see: Viktor Zaslavski, Lo Stalinismo e la Sinistra Italiana: dal Mito dell'URSS alla Fine del Comunismo, Milan: Mondadori, 2004 and Maurizio Degl'Innocenti, Il Mito di Stalin: Comunisti e Socialisti nell'Italia del Dopoguerra, Manduria: Lacaita, 2005.
} 
indeed remember that, even to the socialists most hostile to the communist party, in both countries socialist parties were seldom considered more right-wing than communist parties. Especially during the years immediately following the Liberation, the press, leaflets and speeches of the main political leaders stressed that neither of these parties was more left-wing than the other. Subsequently, it would have been irresponsible to give up on the most obvious symbol of the struggle of the working class in its rise to power. For those in favour of an alliance with the communists, the issue also existed, though in a slightly different way. How could they, in the first place, justify the existence of two parties? And how should they position themselves in relation to the communists? There was also the question of the interpretation of the splits at the Tours and Livorno congresses, namely: how was this period to be construed historically? Was it a temporary division meant to be settled at some future point? Or was it a fundamental and definitive split within the working-class movement? ${ }^{4}$

On this issue, it should be noted that the two parties were not in exactly the same situation. Both were faced with an extremely powerful communist party, which made these unique situations in Europe and justifies the comparison drawn between them here. In France, however, although they collaborated for a while within the National Unity governments, socialists and communists progressively grew further apart until their relationship became bitterly acrimonious. It remained tense during the whole period considered here, and it was only in the 1970s that they once again became close and started building the alliance that brought them to power in 1981. In contrast to this, most Italian socialists were convinced that the division of the working-class movements had led to the advent of fascism and deemed the alliance with the communists necessary. The unitary policy that became known as frontismo continued for the whole period considered here, and only came to a halt in 1956 under the combined effect of the Khrushchev speech and the Hungarian uprising. It was a very isolated position in Europe, to the extent that the PSI had to sever all ties to the Socialist International, which condemned the alliance with the communists. However, this position was not held without internal conflict, and the first years after the war were fraught with divisions, not least of which was Giuseppe Saragat's creation of the Partito Socialista dei Lavoratori Italiani (Italian Workers Socialist Party or PSLI). ${ }^{5}$

It is often held that one's relationship to the October Revolution depended exclusively on the relations that one maintained with the USSR and the communist party; ${ }^{6}$ and it is true to say that the socialists most in favour of an alliance with communists did celebrate 1917 more fervently, and were less critical towards the successive evolutions of the Soviet Union than the members of the SFIO or of the PSLI. And yet, it appears that this causal link has to be partially called into question as it is not because they refused to participate to commemorations organized by and for the communist parties of their countries that socialists gave up on claiming the legacy

\footnotetext{
${ }^{4}$ References on this issue are abundant. See, among others Jean-Jacques Becker and Gilles Candar, Histoire Des Gauches en France, Paris: La découverte, 2004; Donald Sassoon, One Hundred Years of Socialism: the West European Left in the Twentieth Century, London: I B Tauris, 1996; Giovanni Sabbatucci, Storia del Socialismo Italiano, Rome: Il Poligono, 1981, 6 vol.

${ }^{5}$ In 1951, this became the Partito Socialista Democratico Italiano (Italian Socialist Democratic Party or PSDI).

${ }^{6}$ For instance, regarding this issue, Michal Reiman, 'La Rivoluzione d'Ottobre e la sinistra in Europa negli ultimi decenni' in Marcello Flores and Francesca Gori (ed.), Il Mito dell'URSS nella Cultura Occidentale, Milan: Franco Angeli, 1990, p50 mentions an 'unbreakable bond' between an individual's or a party's position towards the USSR and the way they consider the October Revolution.
} 
of 1917 for themselves, even though they were often forced to do so in a less ostentatious way. What is argued here is that, in spite of the obvious disagreements that existed between some socialists on the one hand and the USSR and European communist parties on the other hand, these socialists did not renounce their right to the political symbolism and power born of the Russian revolution, even though their political position - their will not to bow down to the communist party - and their reservation towards the evolution of the USSR forced them to do so in a somewhat convoluted way.

Undoubtedly, some elements did lean towards a direct and unambiguous celebration of the Russian revolution: for instance, a political strategy clearly aimed towards the revolution, a foreign policy leaning towards the Eastern bloc or sympathies with communist parties. But other elements were also relevant and have sometimes been overlooked: for example, the fact that the prestige of the October revolution did not depend exclusively on the bond socialists had with the Russian revolution, as in the years that followed many considered it a founding element that could be isolated from the evolution of the USSR. This event was part of the history of the working-class movement which socialists aligned themselves with, and was therefore a subject of fascination for the whole socialist sphere of influence, politically but also sentimentally and affectively.

\section{'Per la prima volta...': the emotional bond of the Marxist left to October}

During the course of this research, this question of the emotional bond to historical events has emerged as a fundamental one. Political historiography has indeed reassessed the role of various factors that could explain political commitment by underlining the importance of political imagination and representations, and of the emotional relationship to politics that derived from these. ${ }^{7}$ The connection one feels to a historical event is not only determined by a rational approach but is also built in conjunction with affects, emotions, identification and sympathy mechanisms. Thus, this emotional dimension can help explain the attachment of the noncommunist left to the October revolution, even during periods when relations with the communist party were at their worst. Naturally, the way the USSR was perceived remains the main factor that shaped the party's position towards the October revolution, as evidenced by the SFIO's position in the 1940s or 1950s or the PSI's turnaround after the Hungarian rising og 1956. However, this analysis far from exhausts all the subtleties surrounding the October 1917 debate within socialist parties. Several works have shown that it was possible to be hostile to communism without, however, rejecting the Russian revolution, and this was something that

\footnotetext{
${ }^{7}$ After Maurice Agulhon's fundamental works (among which Marianne au Combat: l'Imagerie et la Symbolique Républicaines de 1789 à 1880, Paris: Flammarion, 1979), research on political culture and the importance of emotions in politics has developed over the course of the past decades, in particular with the works of Serge Berstein (for instance, 'L'historien et la culture politique' in Vingtième Siècle. Revue d'histoire, 35, July-September 1992), Jean-François Sirinelli (Histoire des Droites en France, Paris: Gallimard, 1992) or Tony Judt (Marxism and the French Left: Studies on Labour and Politics in France 1830-1981, Oxford: Clarendon, 1990), it has drawn inspiration from the contributions of a more anthropological approach (David Kertzer, Comrades and Christians: Religion and Political Struggle in Communist Italy. Cambridge: Cambridge University Press, 1980), reassessing the cultural dimension of politics (Christophe Prochasson, 'La politique comme culture' in Le Mouvement Social, 200, September 2002) and, more recently, focusing on the history of emotions (Nicolas Mariot, 'Qu'est-ce qu'un "enthousiasme civique" ? Sur l'historiographie des fêtes politiques en France après 1789', in Annales. Histoire, Sciences Sociales, 1, 2008).
} 
was obvious from a very stage, even though the working-class movement was tearing itself apart. ${ }^{8}$ For instance, Nicole Racine quotes Jean Longuet as he stated the socialist guidelines in 1921:

We do not want to be drawn so far into the argument that we forget everything the Russian revolution means to us and what the Soviet Republic embodies nowadays... For all the ways its leaders have wronged us, we shall not forget for a single moment how far above everything else it rises in the history of the world. ${ }^{9}$

The interpretation of the world which marxism implies - and both socialist parties explicitly claimed to adhere to this doctrine - is intrinsically dual. Opposing the defiant proletariat are the reactionary forces that embody outdated interests - capitalism, feudalism, clericalism. Even if the working-class movement suffered profound divisions, the Russian revolution remained a symbol of its victory against reactionary forces and was, in that way, a conquest. Additionally, it served to reinforce the teleological interpretation of the historical process, by highlighting the relentless forward march of the proletariat. It made it possible to acknowledge the entire theory: as the PSI leaders expressed it in a report: '[our] ideal, after the October revolution, is abstract no more, it has become tangible: it is therefore accessible and achievable, not in a distant future but for our generation and our children's'. ${ }^{10}$

Thus, the prestige of the October Revolution stemmed from its capacity to keep Russian feudalism, tsarism and capitalism in check. It stemmed from the sheer power of the movement born from the Revolution and contributed greatly to socialists' sympathies. Even after the split in the movement, when the disunion between socialism and communism could not have been more obvious, French socialists deemed it necessary, in Jules Guesde's words, to 'stand guard' around the Russian revolution that reactionary forces would have been more than happy to knock down.

This belief still prevailed in the years after the end of the Second World War, in a context prone to the exaltation of the revolutionary myth. The link between the 1917 revolution and the First World War was repeatedly stressed and some saw in fascism the ultimate stage of capitalism which necessarily coincided with the coming of age of new revolutions. ${ }^{11}$ Furthermore, the glorification of the working-class movement's role in the Resistance, and the promotion of violent actions as a consequence, resulted in an 'ideological passion for the revolutionary myth'. ${ }^{12}$ It also made the Revolution, in Giovanni Sabbatucci's words, 'a value in itself' ${ }^{13}$ And this revolutionary myth was reinvigorated by Stalingrad and the anti-fascist

\footnotetext{
${ }^{8}$ See in particular Sophie Cœuré, La Grande Lueur à l'Est, les Français et l'Union Soviétique, 1917-1939, Paris: Seuil, 1999, pp120-2.

${ }^{9}$ Quoted by Nicole Racine, 'Le Parti socialiste SFIO devant le bolchevisme et l'Union soviétique, 1921-1924' in Revue Française de Science Politique, 2, 1971, p301.

10 'Appello del PSI ai lavoratori italiani nel $31^{\circ}$ anniversario della Rivoluzione d'ottobre' in Avanti!, 7 November 1948.

${ }^{11}$ It is particularly the case of Italian socialist Lelio Basso, party secretary from 1946 to 1948 . About this, see Roberto Colozza, Lelio Basso, una Biografia Politica (1948-1958), Rome: Ediesse, 2011.

12 Giuseppe Cacciatore, 'La sinistra socialista. Meridionalismo e politica unitaria nel PSI attraverso l'opera e l'azione di Luigi Cacciatore' in Giuseppe Muzzi, La Sinistra Meridionale nel Secondo Dopoguerra (1943-1954), giornate di studio in onore di Francesco De Martino, Florence: Istituto Socialista di Studi Storici, 1991, p87.

${ }^{13}$ Giovanni Sabbatucci, Partiti e Culture Politiche nell'Italia Unita, Rome-Bari: Laterza, 2014, p73.
} 
alliance that boosted Soviet prestige.

And so, the timeless appeal of October 1917 seems to have stemmed from the idea of a revolution that was not exclusively political, as in the nineteenth century, but that was for the first time in history a successful social revolution, as opposed to the failure of the Paris Commune. This idea of victory is key here. The Russian revolution was indeed the only example of a resounding and lasting success at a time when the working-class movement delighted in celebrating its martyrs and in extolling aboritve insurrections - the Paris Commune being the most sensational example among many others, such as Gracchus Babeuf or Carlo Pisacane. Thus, 1917 was the Revolution incarnate, and from this stemmed an immense prestige: it was the first step of a new history that would carry the proletariat to power.

This idea was a crucial one: in the words of an anonymous partisan interviewed by the newspaper Avanti!, what made the power of the Russian revolution was that 'for the first time"14 an organised proletariat had won, the 'working forces have made history', they had gone from 'Utopia to history. ${ }^{15}$ As summed up in the socialist newspaper on 9 November 1945, the Russian revolution was 'the Victory, the beginning of a new kind of history'. ${ }^{16}$ All this is summarised in an article of 1949 by Ferdinand Caussy who described 1917 as 'the most aweinspiring event in history' and went on to add:

'We are not part of those who underestimate the great impact, the absolutely incredible meaning of the Russian revolution [...]. The Russian revolution was a political revolution, but contrary to the French Revolution, it was a social revolution as well; it took upon itself, by abolishing individual property, to end the exploitation of man by the holder of capitals or means of production; it shattered the most ancient foundations of society, it pursued this goal relentlessly, by every mean at its disposal, even the most reprehensible. ${ }^{17}$

The term 'awe-inspiring' ['bouleversant' in French] is interesting in itself as it has a doublemeaning. It conveys the idea of both a radical transformation of the state of the world and of an impressive, even poignant event, pertaining to the emotional sphere. Even though Caussy acknowledged the incredible nature of the revolution, its fundamental role and its incommensurable historical impact, he still mentioned his opposition to the violent methods that were used. In this way he proved that, although he was aware of the founding importance of 1917 , he could not accept it as a whole.

This conception of the revolution, that Nicole Racine deems marked by 'emotions and passions, as always when dealing with a revolution', goes clearly demonstrate an ambivalent relationship to the October revolution. ${ }^{18}$ Some of its political aspects were condemned, but overall it inspired fondness, and this ambivalence was from very early on a crucial aspect of socialists' relationship to October 1917. Incidentally, this emotional involvement with the events of October was also recognised by those concerned; for instance, when Italian socialists

\footnotetext{
14 'La parola ai compagni' in Avanti!, 7 November 1957.

${ }^{15}$ Psi direction press release published in Avanti!, 7 November 1948.

${ }^{16}$ Editorial in Avanti!, 9 November 1945.

${ }^{17}$ Ferdinand Caussy, 'À rebours. À propos de la Révolution d'octobre' in Le Populaire, 8 November 1949.

${ }_{18}$ Nicole Racine, 'Le Parti socialiste SFIO devant le bolchevisme et l'Union soviétique, 1921-1924' in Revue Française de Science Politique, 2, 1971, p301.
} 
explained in 1947 that they felt the 'obligation to reaffirm the sentimental and political bond that links them to the October revolution'. ${ }^{19}$

All of this therefore explains that it was the October revolution that for both Italian and French socialists remained a point of reference, while the February revolution was never truly considered a part of the socialist tradition. Even when tensions with communists were running high, French socialists seldom claimed the Menshevik legacy. Sometimes, especially in strongly working-class areas where there was strong rivalry, some socialists may have claimed the legacy of the February revolution and promoted political pluralism in order to undermine the communists. Nevertheless, they were often met with opposition even within their own party. For instance, Augustin Laurent, former mayor of Lille and former socialist minister, the secretary of the SFIO's powerful Nord federation, attempted to defend the legacy of February and of Kerensky in a congress: 'To be eclectic, to be quite simply true, to be in sync with human truth, there was a very small movement that had a name: the revolution of March 1917. This is when tsarism was overthrown, and from March to October, they're the ones who fought.' Laurent went on to add: 'It is untrue to say that within the Socialist Democrat Party, Kerensky represented the rich farmers of Russia. ${ }^{20}$ But at that moment, he was interrupted by a rumble of disapproval which proves that, even in a French department where the confrontation with communists was tough and sometimes even violent, October was better liked than February. Within the SFIO, the broad majority condemned 'Kerensky's bourgeois government' and saw in Lenin's victory 'the victory of the people.' ${ }^{21}$ That being said, celebrations were rarely straightforward and the SFIO used various back-door methods of paying respects to October 1917.

\section{Two different historical accounts}

French socialists thus seldom marked the occasion as the anniversary of the revolution in itself, but rather as another country's national day, to which one would address formal congratulations. Every November, the socialist press was oddly discreet on the subject. Only a few articles tackled the issue directly, and these were rarely written by major party leaders. Conspicuously, every effort seems to have been made to disregard the fact that it was an anniversary date. Even better, November was often the time chosen by the socialist press to publish series of articles on socialist countries' accomplishments: Labour England, Norway or Sweden, for example. ${ }^{22}$ Faced with communist firepower and the PCF newspaper L'Humanite's commemorative articles, it seems that socialists chose a low-key response, as if not to enter a competition they would inevitably lose.

When they nonetheless ventured towards these celebrations, it was most often to cast doubt

\footnotetext{
19 'Il valore universale della Rivoluzione d'Ottobre' in Avanti!, 7 November 1947.

${ }^{20}$ Archives départementales du Nord, Archives de la fédération socialiste, b.62, 'Compte-rendu du congrès fédéral, 6 octobre 1948'.

${ }^{21}$ René Bondois, 'Lénine, toujours présent !' in L'Avenir du Nord, 5 January 1945.

${ }^{22}$ For instance, a series of articles were published by Marcel-Edmond Naegelen in Le Populaire, on Sweden, Norway and Finland from November $6^{\text {th }}, 1945$. Other articles on Labour England were published in La Revue Socialiste in November 1946.
} 
on communist commemorations, by trying to break the connection the latter drew between 1917 and contemporary USSR or by underlining the PCF's dependence on its Soviet counterpart, both organisationally and semantically. In 1948, for instance, Henri Noguères ridiculed the speech of PCF leader Maurice Thorez published in L'Humanité: the 'sacrosanct catchphrases approximately translated from Russian - he is required to use in such circumstances. The great Stalin, leader of the international proletariat, father of nations, founder of socialism, is saluted, lauded, praised as is appropriate. ${ }^{23}$

However, the lack of official celebrations on anniversary dates does not mean that French socialists gave up on celebrating the Revolution and claiming its legacy for themselves, but rather that they did so at other times and on other occasions. These celebrations, moreover, built on the lexical field of a perverted, betrayed revolution. The revolutionary power of the Russian proletariat was glorified, but what had followed was condemned: so, for instance, Jules Moch, who was famous for his stormy relations with the communists, cried out: 'Stalin is no more Lenin's continuator than Napoleon was Robespierre's. ${ }^{24}$

Likewise, the hostile brochures circulated by socialists against the communist party emphasized the idea that the CPSU had wrecked an initially spectacular achievement, and thus in this way they never questioned the October revolution itself. Instead, they insisted on the discrepancy between October and the USSR as it then existed by publishing a list of members of the party executive who had carried out the insurrection and who had subsequently all been eliminated on Stalin's orders. ${ }^{25}$ The character of Stalin attracted the majority of the attacks: French socialists did not let him present himself as the rightful heir to October, and according to them he was responsible for its achievements being led astray. In the article previously mentioned, Caussy played down Stalin's importance in the revolutionary events of October 1917 and instead summoned Trotsky who enjoyed a certain prestige in some socialist branches. Trotsky also had the undeniable advantage of not being associated with later developments in the USSR:

The actual originator of the October Revolution is Trotsky. Trotsky who, when he boldly decided to attack the Leningrad Phone Centre, while Lenin was dithering and Stalin was hiding, gave the decisive impetus that brought Victory. The distortions of the truth that have been printed since then in hundreds of millions of copies, or that have been expressed just yesterday by [leading French communist, Etienne] Fajon, will not change anything of this!

So the celebration of October by French socialists took the form of the celebration of a historical event, confined in time, once remarkable, but since then unfortunately led astray. Those celebrations tended to remove the October revolution completely from its context. It became

\footnotetext{
${ }^{23}$ Henri Noguères, 'Quand M. Thorez veut enseigner l'histoire dans un meeting au Vel d'Hiv' in Le Populaire, 6 November 1948.

${ }^{24}$ Speech given in Phalempin in front of 50000 people and published in L'Avenir du Nord, 7 August 1949.

${ }^{25}$ Fondation des Sciences Politiques, Archives Daniel Mayer, 1MA 4 - PCF, Anticomunist leaflet, 'Un parti révolutionnaire?', released at the end of the 1940s : 'Trotsky, founder of the Red Army, murdered in Mexico by a GPU agent. Zinoviev, executed on Stalin's order. Kamenev, executed on Stalin's order. Rikov, executed on Stalin's order. Tomski, executed on Stalin's order. Stalin, only survivor'.

${ }^{26}$ Ferdinand Caussy, 'À rebours. À propos de la Révolution d'octobre' in Le Populaire, 8 November 1949.
} 
the epitome of the proletariat's victory against reactionary forces. As such, it had to be glorified; but as no current reality matched up to it, it was envisioned as an isolated historical event.

The exact opposite took place in Italy. There, the celebration of the Russian revolution was in fact a celebration of the USSR. As Pietro Nenni himself said, the celebration was meaningful mainly because it was a worldwide communist commemoration which joined together millions of people:

On this very afternoon, in all the major cities of the world, masses of workers (men and women) are, like us here in Rome, gathered to confirm their friendship and their solidarity with the Soviet Union on this, the 30th anniversary of the October revolution. ${ }^{27}$

The way time was envisioned thus differed greatly from what was taking place in France: in Italy, there was a direct link or continuum between 1917 and its current celebration, which was the celebration of a country, of a revolutionary state. Because the October commemorations were a celebration of the USSR, every major achievement was remembered: the defeat of tsarism, the victory of Stalingrad, the struggle for world peace. The connection to the original historical event was therefore completely different. It was not, as for French socialists, the celebration of an isolated event which was an admittedly important yet incomplete milestone in the proletariat's progression to a classless society. On the contrary, the revolution was still in progress and, by celebrating it, Italian socialists reaffirmed that it was more noteworthy than ever and still immensely powerful. While the SFIO commemorated an event, the PSI exalted a process. Therefore, the anniversary date did not take on the same meaning at all: it was a mere memorial in France, but in Italy still the focus of ongoing struggle. It was a collective celebration that had the same importance as May First, a token of solidarity towards the USSR, a collective ritual as well as a political declaration of faith. Hence the socialist newspaper Avanti! wrote about the 1949 ceremony:

Gathered around their socialist flags, the Italian workers demonstrated in unison with millions of other workers around the world. As well as the celebrative aspect, the demonstrations assume a political significance which is not to be underestimated, confirming that the socialists and communists of Italy are on the front line in the struggle of the international working class. ${ }^{28}$

It is also remarkable that, as the PSI had been expelled from the COMISCO - the Committee of the International Socialist Conference - it did not belong to an international organisation anymore. The International mentioned in the articles was therefore purely fictional and symbolic, and it was another crucial benefit of the commemoration that it allowed the PSI to be part of a de facto International.

The PSI created the Italy-USSR association with the communist party and took part in all the association's official commemorations. ${ }^{29}$ Its founding congress took place in 1949, at a time when the frontismo policy was being reasserted. Among the members of the association's

\footnotetext{
${ }^{27}$ Speech given on 7 November 1947 published in Avanti!, 8 November 1947.

28 'Manifestazioni in tutta Italia, il 32 anniversario della Rivoluzione d'Ottobre', in Avanti!, 8 November 1949.

${ }^{29}$ Regarding this issue, see Maurizio Degl'Innocenti, Il Mito di Stalin, op. cit.
} 
executive committee were socialists such as Jaurès Busoni and Raniero Panzieri, but also women of the families of the main leaders of the PSI such as Giuliana Nenni, Pietro Nenni's daughter or Carla Pertini, Sandro Pertini's wife. ${ }^{30}$ Police reports show that during the whole 1945-55 period, socialists shared public platforms with communists. To maximise their effectiveness, both parties tried to organise as many meetings as possible so as to emphasise the Italy-USSR 'week of friendship'. As a consequence, some meetings were organised by the socialists alone for a public that could be both socialist or communist, which once more proves how closely involved the PSI was in these ceremonies. ${ }^{31}$

In this close relationship with the communists, socialists could not just turn a blind eye to the issue of the split at Livorno which was the direct consequence of the events of 1917 in Russia. With undeniable sophistic talent, they went as far as presenting this split as a 'division of tasks within the working class'. ${ }^{32}$ It was almost as if it had been methodically and purposely orchestrated, allocating revolutionary tactics and working-class issues to the communists and intellectual and middle-class issues to the socialists.

The PSI was likewise forced to justify a number of soviet deviations from the correct path that it had been pointing out a few years earlier, including on burning issues such as freedom of speech, the single-party system and democracy. ${ }^{33}$ Evasively, it condemned the imperialistic pressure exerted on the USSR and the absence of a world revolution which compelled it to adopt a tactic of defence which was admittedly flawed but undoubtedly also temporary. For instance, in a 1948 press release of the PSI leaders we find the statement that 'every fight and every human victory has a cost' and reminding readers that even the French revolution had had a violent stage at one point. It was consequently 'only when socialism is fully and universally achieved' that it could guarantee that it would 'have the power to shift the political struggle to a higher stage where cruelty, violence and terror will be considered as infamous testimonies from an outdated era'. ${ }^{34}$

It was only after the Khrushchev speech and Hungarian uprising that a dissociation between the Russian revolution and the USSR began to take place, just as among the French socialists ten years earlier. For instance, in an article published by the Mondo operaio in July 1956, Nenni went back to the original position held by the Italian socialist party in the 1920s, seemingly overlooking the position held by the PSI during the previous years:

Even though socialists put themselves firmly and unreservedly in defence of the October Revolution, they refused at that time to identify with it or with the Soviet Union. From this point of view, 36 years on, we can soundly

\footnotetext{
${ }^{30}$ Istituto Gramsci, PCI - 1955, Estero, 0431.805, Asso. Italia-URSS.

${ }^{31}$ The study of the police reports kept at the Archivio Centrale dello Stato in Rome (especially the series Ministero dell'Interno, Gabinetto, Fascicoli correnti) makes this very clear.

${ }^{32}$ Giuseppe Petronio, 'Esame di coscienza di un socialista' in Mondo operaio, 11 November 1956.

${ }^{33}$ Inspire of the Popular Front policy, the PSI had kept, before the war, a certain freedom of speech, and for instance it unequivocally condemned the 1930s trials, like Nenni who believed that : 'if the Revolution has the right to be uncompromising, it also must be fair' in Nuovo Avanti, 22 December 1934. For more details, see Sabbatucci Giovanni, Partiti e culture politiche op. cit. p91.

34 'Appello del PSI ai lavoratori italiani nel $31^{\circ}$ anniversario della Rivoluzione d'ottobre' in Avanti!, 7 November 1948.
} 
confirm the choices made in $1920 .^{35}$

\section{October 1917: a national or a universal impact?}

If both parties' positions on the 1917 events are taken into consideration, it appears that they both tried to isolate within the revolution what pertained to the Russian context, on the one hand, and what had an international impact on the other. For the French, this was a way to celebrate the revolution without praising the USSR; and, most importantly, it undermined the theoretical founding principles of the Cominform by affirming that this revolution had to do exclusively with the history of socialism in Russia and therefore could not be replicated elsewhere. According to this position, the communists' error lay in their desire to impose a national event onto other countries, and the Cominform accordingly was condemned as a testimony to the USSR's uncalled-for hegemonic dynamic.

This also allowed French socialists to recognise the Russian revolution while still picking out those aspects they wished to endorse and distancing themselves from the more violent outbursts they associated with an Asiatic socialism often characterised as tyrannical and violent. To this end, they reclaimed a number of elements shaped by European socialist parties at the time of the revolution and its aftermath, which allowed them considerable flexibility in the way they presented their arguments. For those less hostile to the USSR, this was a way of putting into perspective those aspects of the Soviet experience that were most upsetting to Western European democrats. Sophie Cœuré has shown how this mechanism worked in the case of the French Radical Party leader Edouard Herriot: 'The fact that Russia is essentially different is largely dwelled upon by Herriot, because it allows him to put into perspective the criticism concerning poverty, the brutal socialisation of industry and the absence of freedom of thought and the separation of powers. ${ }^{36}$ The corollary to this argument was that the Russian revolution could not be 'an exportable item', which made it possible to draw a line under the event and exclude 1917 as a point of reference. ${ }^{37}$

In Italy, Pier Paolo d'Attorre has shown how extensively nineteenth-century Russian stereotypes about 'cruelty, paganism, authoritarianism' were reused in Europe in 1917 in reference to the revolution. ${ }^{38}$ They were sometimes used again in the $1940 \mathrm{~s}-50 \mathrm{~s}$ so as to emphasise the importance of the October revolution while underlining the particularity of the Russian context and thus proving the impossibility of replicating it elsewhere in Europe. In this regard, an article of 1947 by Armand Coquart called 'The Origin of Bolshevism' was emblematic of the SFIO's strategy:

Indeed Lenin's party is of a new kind compared to other socialist parties, but of a new Russian kind more than anything else. Its distinctive features can be explained by the national context, by the unique situation of this vast country,

\footnotetext{
${ }^{35}$ Pietro Nenni, 'Primo bilancio sulla polemica sul XX Congresso di Mosca' in Mondo operaio, 7, July 1956.

${ }^{36}$ Sophie Cœuré, La Grande Lueur à l'Est, op. cit. pp121-2.

37 Jules Moch quoted by Sophie Cœuré, Ibid.

${ }^{38}$ Pier Paolo d'Attorre, Nemici per la Pelle, op. cit. p28.
} 
still almost half feudal, where, within the great masses, still half asleep from an age-old torpor, the pressure of capitalism has allowed an ever-growing proletariat to appear. They are connected to historic traditions that were elaborated over the course of a half-century fraught with violence and convulsions - attacks, conspiracies, guerrillas between the police and secret societies - which were rather expected episodes for a people used to expressions of intolerance, to the fanaticism of sects, to the brutality of schisms. ${ }^{39}$

This is a position that can also be found among some Italian socialists. Chief among them was Lelio Basso, who had refused to include within the traditional marxist corpus the analyses of Lenin that he felt so sceptical about. Basso indeed considered that these analyses were but a national adaptation of marxism, as each country was required to adapt the original theory to its own particular context. Lenin and the 1917 revolution were therefore perfectly legitimate in a Russian context but could not possibly provide a universal model applicable to every country. Initially developed by Basso immediately following the Second World War, this idea was still more powerfully expressed once the PSI distanced itself from its communist ally:

Forty years ago, Italian socialists not only paid tribute to the first Revolution in history that aimed to establish Socialism, but they encouraged it through their efforts and their support [...]. But at the same time, Italian socialists turned down Moscow's twenty-one points, already convinced, as we still are, that our reality cannot be forced into anything, that it is so different from the Russian context, and that it is impossible to build a valid universal model to progress towards Socialism. ${ }^{40}$

Nevertheless, this position was overall a minority one, and most Italian socialists insisted upon the exemplary dimension of 1917 . They branded it 'a heritage of humanity', ${ }^{41}$ praised its 'creative power', ${ }^{42}$ and therefore considered it an example to follow. Their position therefore was closer to that of the communists: for them, the Russian revolution, with its 'national and universal' ${ }^{43}$ reach could serve as a model for each and every further revolutionary episode and its celebration did not belong 'to a single country or a single party' ${ }^{44}$ but to the whole of humankind.

This idea clearly appeared in the international socialist movement in the ongoing debates regarding the revolution as point of reference. Indeed, in both countries, the socialist parties were built on a combination of marxism and democratic values inherited from the French revolution. Both agreed on the fact that the French revolution was a fundamental starting point, following which feudalism was defeated and democracy was able to gain strength even in spite of various bumps in the road. Thus in France, despite all the criticism it faced, and the disappointed hopes in a process of social transformation, the French revolution remained a point of reference in that it had allowed a democratic system to develop, and brought political

\footnotetext{
${ }^{39}$ Armand Coquart, 'Genèse du bolchevisme' in La revue socialiste, 14 October 1947.

${ }^{40}$ Lelio Basso, 'Coerenza socialista' in Avanti!, 7 November 1957.

${ }^{41}$ Rodolfo Morandi, quoted by Fabrice d'Almeida, Histoire et Politique en France et en Italie : l'Exemple des Socialistes. 1945-1983, Rome: Presses de l'École française de Rome, 1998, p120.

42 Tullio Vecchietti, 'Un impegno di lotta' in Avanti!, 7 November 1952.

${ }^{43}$ Editorial, Avanti!, 9 November 1945.

${ }^{44}$ Lucio Luzzatto, 'Un valore permanente' in Avanti!, 7 November 1953.
} 
freedom to the people. Following the political revolution of 1789, the SFIO hoped for a social revolution, although the term 'revolution' remained ambiguous and was never precisely defined. ${ }^{45}$ In their system of representation, 1917 was but a step towards the social revolution, like the Paris Commune. They did not consider the USSR a socialist state, and the social revolution therefore did not have a model in which this ideal of revolution was embodied. The PSI, by contrast, was unequivocal about the issue: for them, the October revolution was the only authentically socialist one. Nenni called it 'the greatest revolution in history' 46 and undoubtedly ranked it above 1789 because it was able to 'destroy capitalist relations of production and suppress bourgeois freedom, thus liberating millions of peasants and workers and showing them the way to a superior civilisation' ${ }^{47}$

This was a very common refrain, often used by socialist speakers in drawing the comparison between both revolutions, and became one of the most popular themes in the early November commemorations. For instance, in a public meeting held for the anniversary in Benevento on 7 November 1954, PSI section secretary Carmelo Ricci drew 'a parallel between the Russian revolution and the 1789 French Revolution, underlining the greater success of the former' ${ }^{48}$ In spite of all, it was nevertheless obvious that the second revolution could not have taken place without the first, and the PSI was commonly presented as the party that could make a synthesis between the two revolutions, as proposed by Nenni at the party's twenty-fifth congress in 1947:

What does the West mean to us? It is that part of the world that has brought forward and strengthened freedom of thought, freedom of conscience, individual freedom through the fights of the most advanced elements [...]. What does the East mean to us? It is that part of the world that, thirty years ago, achieved one of the greatest Revolutions in history and defended it against the Capitalist world.

According to Nenni, all countries go through the two phases of political revolution and social revolution and Russia was no exception. He therefore drew a parallel between 1789 and the February revolution that put an end to tsarism but was weak and had risked being as short-lived as its French predecessor. And so, 'the most elegant speakers of the February revolution, like the French Girondins, talked about freedom, about justice, about progress, and it delighted lawyers, professors and journalists. But they were not able to defeat the conservative forces for good', which irremediably drove the revolution to 'to put itself and the people at risk of a counter-revolution. ${ }^{49}$ All this naturally made the October revolution seem all the more valuable, as its goal was to preserve what had been already been conquered as well as to impose new social victories. By emphasising October over more political revolutions, Nenni as PSI leader thus forcefully reaffirmed the necessity to regard Soviet Russia as an example, as it was

\footnotetext{
${ }^{45}$ There are a number of debates on this issue within the party that are not easy to sum up here. Léon Blum's main idea, that resonates with many within the SFIO, is that it is not by seizing the power but by enacting the socialist transformation of society that a Revolution succeeds. It can therefore be the consequence of either an armed insurrection or of a legal and democratic coming to power, the latter being an increasingly popular option.

${ }^{46}$ Pietro Nenni e Palmiro Togliatti, Viva la Rivoluzione d'Ottobre, Discorsi Pronunciati a Roma il 12 Novembre 1944, Rome: Società Editrice Unità, 1945.

${ }^{47}$ Pietro Nenni, 'Sbaglio indirizzo' in Avanti!, 18 January 1948.

${ }^{48}$ Police Report, 8 November 1954. Archivio Centrale dello Stato, Ministero dell'Interno, Gabinetto, Fascicoli correnti, 1953-1956, b. 32.

${ }^{49}$ Pietro Nenni e Palmiro Togliatti, Viva la Rivoluzione d'Ottobre, op. cit.
} 
more than ever 'an experience to ponder and a lesson to draw from, ${ }^{50}$, especially for countries like Italy that had only gone through the first stages of the process.

This issue of the exemplarity of the October revolution, however, calls for comment: for how much, indeed, was it really to be considered as if an actual instruction manual to be carefully followed? As everyone seemed to acknowledge the differences between tsarist Russia in 1917 and Italy in the same period - and even more so, the differences with 1940s and 1950s Italy - how valuable could this 'lesson' they all referred to really have been? Should one understand it as a theoretical model to be looked up to when wishing to seize power by means of insurrection? This is highly unlikely, as the actual lessons to be drawn from the 1917 events were relatively trivial. Moreover, subsequent historiography has shown that, in spite of an overtly revolutionary imaginary and rhetoric, neither socialists nor communists actually had insurrectional designs. ${ }^{51}$ They did not go as far as condemning violence, and they even considered it a legitimate mode of action: in that perspective, 1917 was the definite proof that the reformist way was not the only one worth considering for working classes. So, for imaginations overwhelmed by the revolutionary myth, 1917 represented an ideal model, a symbol of the way in which a society could tip over and the proof that the proletariat could be the master of its own destiny. But in spite of the party's public statements, October could not really be considered as a guideline they would follow, so the commemoration remained a symbolic one - the celebration of an event whose evocative power derived first and foremost from its absolute novelty.

\section{After Budapest}

In concluding, something must be said about the Budapest events which marked a definite turning-point for Italian socialists. Khrushchev's speech had already contributed to driving the PSI away from its communist ally, and the Hungarian rising precipitated the split, as evidenced by the October celebrations which that year were held separately in some places for the first time in a long while. If they did not definitely abandon the Russian revolution, Italian socialists did start celebrating it very differently; like the SFIO, they dissociated the revolutionary event from the USSR and also began to consider it a revolution led astray. In practice they thus returned to the position once held by the majority of western socialists: one leaflet for instance described the soviet intervention in Hungary as 'the degeneration of the people's power into bureaucracy and policing. ${ }^{52}$ Nenni conveyed the same general idea; but as he continued to acknowledge the importance of 1917, he henceforth isolated it from the years that had followed in the USSR:

The October Revolution would not have survived the civil war stage and the foreign imperialist intervention, without the indomitable willpower of the

\footnotetext{
${ }^{50}$ Editorial, Avanti!, 9 November 1945.

${ }^{51}$ For instance, see Marc Lazar, Maisons Rouges : les Partis Communistes Français et Italien de la Libération à nos Jours, Paris: Aubier, 1992; Giuseppe Carlo Marino, Autoritratto del PCI Staliniano: 1946-1953, Rome: Editori riuniti, 1991 et Pietro Di Loreto, Togliatti e la 'Doppiezza'. Il PCI tra Democrazia e Insurrezione 1944-1949, Bologne: II Mulino, 1991.

${ }^{52}$ Socialist leaflet spread in Cagliari, 6 November 1956 (Archivio Centrale dello Stato, Ministero dell'Interno, Direzione Pubblica sicurezza, Affari generali, 1956, b.4).
} 
Proletariat who succeeded in taking possession of the Tsarist State's machinery of power, in knocking it down and in replacing it. But at the same time, it would be absurd to turn a blind eye to the fact that the proletarian dictatorship became a personal dictatorship of Stalin and it therefore lies outside of the expectations of the founders of socialism. ${ }^{53}$

Socialists were thus immediately drawn to the Hungarian insurgents, who were seen as continuators of the revolutionary process. The sentimental connection to the revolution evoked earlier on was entirely at work here: and for socialists who continued to be fascinated by the legend of revolution, how could they fail to be captivated by the example of an insurgent people confronted with brutal military repression? The very same revolutionary mythology used to celebrate October was thus re-employed to the benefit of the Hungarian people. For instance, in Cremona, a joint poster of the PSI and PSDI - successor to the PSLI - 'condemn[ed] the degeneration of the people's democracy', exalted the 'Magyar revolution' and 'bid an emotional farewell to the victims of repression and the men who fell in this tragic conflict who will fraternally join the ranks of their fellow martyrs for the redemption of the working class'. ${ }^{54}$

But even though they were distancing themselves from the USSR, socialists were also keeping intact the revolutionary myth of October. Even better, they continued to establish a link between each and every revolution and 1917. For instance, Lelio Basso, as he condemned the Russian intervention, reminded everyone what the world owed the October revolution:

As socialists, we cannot forget another incredible historical merit of the soviet revolution, $[\ldots]$ that it opened the doors to the second magnificent revolution that is taking place before our eyes, the emancipation of the Asian and African people. $^{55}$

In France, even though for the first time since the 1920 split a French socialist delegation had travelled to the USSR, thus marking a new beginning in the relationship between the two, the Hungarian revolution seemed to confirm the SFIO's longstanding analysis; that the USSR had definitely degenerated into a despotic bureaucracy. ${ }^{56}$ This episode reinforced the decline of the prestige of the 1917 revolution, and celebrations here weakened more quickly than in Italy. However, it would be a mistake to think that the decline of interest in the Russian revolution was caused by a lack of interest in revolutions in general. In fact, even if the Guy Mollet government seemed very distant from the revolutionary ideals, affection and sympathy for the revolutionary episodes mentioned earlier were still intact. The revolutionary myth endured and French socialists saw in Budapest and its barricades a revolutionary protest to which they were drawn almost instinctively. A few articles proclaimed the solidarity of the 'Successors of the

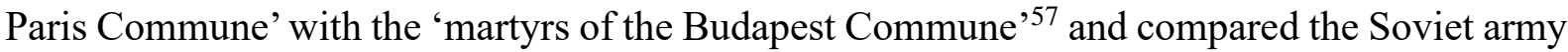

\footnotetext{
${ }^{53}$ Pietro Nenni 'Problemi del Socialismo: il rapporto Krusciov e la polemica sul Comunismo' in Mondo Operaio, 6, June 1956.

${ }^{54}$ Archivio Centrale dello Stato, Ministero dell'Interno, Direzione Pubblica sicurezza, Affari generali, 1956, b.4.

${ }^{55}$ Lelio Basso, 'Coerenza socialista' in Avanti!, 7 November 1957.

${ }^{56}$ For the delegation to the USSR, between 30 April and 14 May 1956, see Jean-Paul Brunet, 'Socialisme et bolchevisme. L'image de la révolution d'Octobre et de l'Union Soviétique chez les socialistes français en 1956' in Revue française de science politique, 1989, vol.39, p700-15.

57 'Les héritiers de la Commune de Paris ont proclamé hier leur solidarité avec les martyrs de la Commune de Budapest' in Le Populaire, 10-11 November 1956.
} 
to the 'Versailles army'58 which in 1871 had cracked down on rebel Paris. The revolutionary mythology still mesmerised socialists indeed.

${ }^{58}$ Suzanne Labin, ‘À propos d'un anniversaire’ in Le Populaire, 2-3 November 1957. 